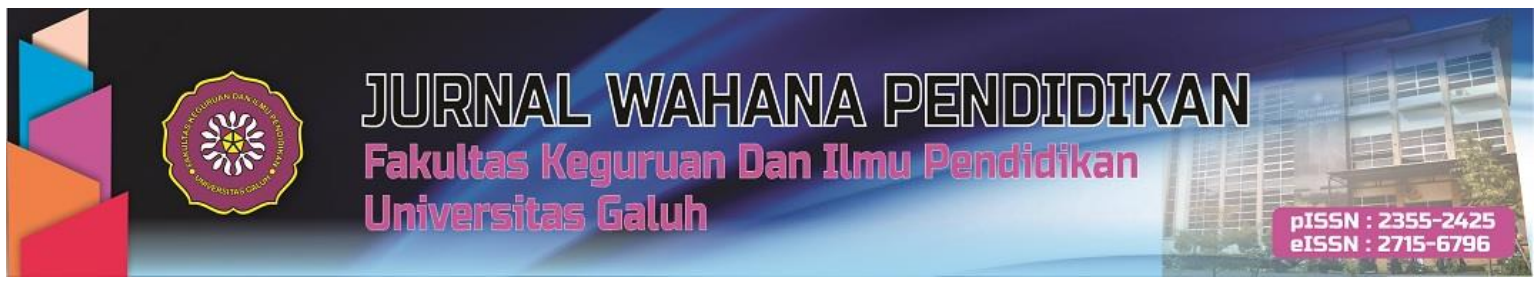

https://jurnal.unigal.ac.id/index.php/jwp/article/view/3612

\title{
UPAYA MENINGKATKAN PEMAHAMAN KALIMAT PASIF (PASSIVE VOICE) SISWA PADA BERBAGAI TENSES MELALUI METODE DRILL
}

\author{
Nana Setia Permana ${ }^{1}$ \\ 1SMK Negeri 1 Pangandaran, Jalan Merdeka No.222, Pangandaran \\ Email: nanapnd48@gmail.com
}

\begin{abstract}
The purpose of this research is to describe the learning process through the drill method and determine the effectiveness of the method to improve students' understanding of class XI RPL 1 SMK Negeri 1 Pangandaran in the academic year 2017/2018 about passive voice at various tenses. The variable that is the target of change in this study is student understanding, while the action variable used in this study is the drill method. The form of this research is classroom action research which takes place in two cycles. Each cycle consists of 4 stages, namely planning, implementing actions, observing, and reflecting. The research subjects were students of class XI RPL 1 SMK Negeri 1 Pangandaran in the academic year 2017/2018, totaling 35 people. The data collection techniques used were observation and tests. The data analysis technique used is qualitative, which consists of three main stages, namely data reduction, data exposure, and conclusion drawing. The results of this study state that the drill method is proven to improve students' understanding of class XI RPL 1 SMK Negeri 1 Pangandaran in the academic year 2017/2018 about the review text. The results showed that there was an increase in the level of mastery of the material (class average value) by $13.2 \%$. While the increase in the percentage of learning completeness was $74.3 \%$. In addition, the drill method is proven to be able to improve the behavior of class XI RPL 1 students when the learning process takes place.
\end{abstract}

ABSTRAK
Tujuan penelitian ini mendeskripsikan proses pembelajaran melalui metode drill dan mengetahui efektifitas metode untuk meningkatkan pemahaman siswa kelas XI RPL 1 SMK Negeri 1 Pangandaran tahun pelajaran 2017/2018 tentang kalimat pasif (passive voice) pada berbagai tenses. Variabel yang menjadi sasaran perubahan dalam penelitian ini adalah pemahaman siswa sedangkan variabel tindakan yang digunakan dalam penelitian ini adalah metode drill. Bentuk penelitian ini adalah penelitian tindakan kelas yang berlangsung dalam dua siklus. Tiap siklus terdiri dari 4 tahapan yaitu perencanaan, pelaksanaan tindakan, observasi dan refleksi. Subyek penelitian adalah siswa kelas XI RPL 1 SMK Negeri 1 Pangandaran tahun pelajaran 2017/2018 yang berjumlah 35 orang. Teknik pengumpulan data yang digunakan adalah observasi dan tes. Teknik analisis data yang digunakan adalah secara kualitatif yang terdiri dari tiga tahap pokok, yaitu reduksi data, paparan data dan penarikan kesimpulan. Hasil penelitian ini menyatakan bahwa metode drill terbukti dapat meningkatkan pemahaman siswa kelas XI RPL 1 SMK Negeri 1 Pangandaran tahun pelajaran 2017/2018 tentang teks ulasan. Hasil penelitian menyatakan bahwa ada peningkatan dalam tingkat penguasaan materi (nilai rata-rata kelas) sebesar $13,2 \%$. Sedangkan peningkatan dalam persentase ketuntasan belajar sebesar $74,3 \%$. Selain itu, metode drill terbukti dapat meningkatkan perilaku siswa kelas XI RPL 1 ketika proses pembelajaran berlangsung.

Kata Kunci: Metode Drill

Cara sitasi:

Permana, N. S. (2020). Upaya Meningkatkan Pemahaman Kalimat Pasif (passive voice) Siswa pada Berbagai Tenses melalui Metode Drill. Jurnal wahana pendidikan, 7 (2), 177-184. 


\section{PENDAHULUAN}

Sebagai bahasa internasional, sudah tidak diragukan lagi bahwa semua orang di seluruh dunia mengenal bahasa Inggris. Bahasa Inggris diajarkan hampir di semua belahan dunia ini. Sebagaimana yang dikatakan oleh Richard dan Rogers, "Bahasa Inggris adalah adalah pelajaran yang paling banyak dipelajari, lima ratus tahun yang lalu bahasa Latin lah yang paling banyak dipelajari". Faktanya, saat ini bahasa Inggris adalah bahasa asing yang paling banyak dipelajari orang di seluruh penjuru dunia.

Ada empat keterampilan bahasa Inggris yang harus dikuasai siswa seperti berbicara, mendengarkan, membaca dan menulis. Selain keempat keterampilan itu, siswa juga harus menguasai Grammar (tata bahasa) bhasa Inggris dengan benar. Setiap orang yang berbicara sebuah bahasa maka harus memahami grammar/tata bahasanya. Ketika ahli bahasa ingin mendeskripsikan suatu bahasa, mereka mencoba menggambarkan tata bahasa yang ada di benak penuturnya. Ada beberapa perbedaan antara pengetahuan penutur, karena tata bahasa inilah yang memungkinkan untuk berkomunikasi melalui bahasa. Dari teori di atas kita tahu bahwa tata bahasa harus diajarkan dengan tepat karena itu adalah elemen dasar dari suatu bahasa. Tanpa pengetahuan tata bahasa yang tepat, siswa akan menemukan banyak masalah untuk mengekspresikan ide-ide mereka dan membangun kalimat untuk komunikasi (Mulyadi, 2019). Ada banyak aspek yang dibahas dalam tata bahasa Inggris. Salah satunya adalah kalimat pasif. Kalimat pasif paling sering digunakan ketika tidak diketahui atau tidak penting untuk mengetahui dengan tepat siapa yang melakukan suatu tindakan. Berdasarkan hasil pengamatan awal terdapat beberapa masalah yang muncul terutama siswa yang ingin memahami kalimat pasif karena kalimat pasif sangat berbeda dengan kalimat aktif.

Peneliti menemukan bahwa sebagian besar siswa memiliki masalah dalam memahami pola Grammar. Hal itu dibuktikan dengan skor pre-test yang rendah. Selain itu, teknik pembelajaran yang monoton menjadi penyebab rendahnya antusiasme siswa dalam mempelajari kalimat pasif. Kalimat pasif sering digunakan baik dalam bahasa Inggris lisan dan tulisan. Di mana, menurut Swan "Kalimat Pasif sangat umum dalam penulisan ilmiah, dan jenis ekspresi lain di mana kita paling tertarik pada peristiwa dan proses: dalam hal-hal yang terjadi".

Para siswa terkadang membuat kesalahan dalam menulis irregular past participle (V3). Misalnya, 'thrown' (past participle dari throw) ditulis 'thrawen', 'taught' (past participle dari teach) ditulis 'tought' atau 'teached'.

Berikut ini adalah kesalahan siswa dalam membuat kalimat pasif dari kalimat berdasarkan hasil pre-test dan pre observasi:

1. Mereka membuat kesalahan dalam mengubah objek kalimat aktif menjadi subjek kalimat pasif.

2. Mereka membuat kesalahan dalam menggunakan "to be" yang tepat pada kalimat pasif dengan tense yang digunakan dalam kalimat aktif dan dengan jumlah subjek, apakah subjek tersebut tunggal atau jamak.

3. Mereka membuat kesalahan dalam menggunakan past participle (kata kerja 3).

4. Mereka membuat kesalahan dalam tenses.

Maka dari itu, penting bagi siswa yang mempelajari Bahasa inggris untuk memiliki pemahaman yang baik tentang kalimat pasif. Sehingga, siswa harus diajarkan dengan menggunakan metode yang terfokus pada kemampuan Grammar. Disini peneliti menggunakan "Drill" sebagai strategi untuk menyelesaikan masalah ini. Drill tidak dapat diselesaikan tanpa siswa memahami sintaks dan semantik dari apa yang dia katakan. Dari deskripsi diatas, peneliti berniat melakkan penelitian tindakan kelas terkait materi kalimat pasif (passive voice) pada berbagai tenses. Penelitian tindakan kelas adalah satu bentuk refleksi mengajar seseorang, yang dilaksanakan dengan cara menumpulkan data pada setiap pertemuan dan menganalisanya, supaya sampai ada satu keputusan tentang langkah apa yang harus diterapkan dimasa yang akan datang. Dalam melaksanakan penelitiam tindakan kelas ini, peneliti memilih siswa kelas XI RPL 1 SMK NEGERI 1 Pangandaran tahun pelajaran 2017/2018. Alasan memilih siswa tingkat XI karena sesuai denga silabus pembelajaran di tingkat tersebut yang mempelajari kalimat pasif. Dalam penelitian ini, peneliti memfokuskan kajiannya pada peningkatan pemahaman kalimat pasif dari perfect tense. Sehingga berdasarkan hal tersebut, peneliti memberikan 
judul untuk penelitannya "Peningkatan pemahaman kalimat pasif (passive voice) pada berbagai tenses melalui metode Drill siswa XI RPL 1 SMK Negeri 1 Pangandaran Tahun Pelajaran 2017/2018.

Pokok permasalahan penelitian ini adalah sebagai berikut:

1. Bagaimanakah penerapan metode drill dalam proses pembelajaran kalimat pasif (passive voice) pada berbagai tenses di kelas XI RPL 1 SMK Negeri Pangandaran tahun pelajaran 2017/2018?

2. Apakah penggunaan metode drill dapat meningkatkan kemampuan memahami kalimat pasif (passive voice) pada berbagai tenses siswa kelas XI RPL 1 SMK Negeri Pangandaran tahun pelajaran 2017/2018?

Tujuan utama penelitian ini adalah sebagai berikut:

1. Untuk mendeskripsikan penggunaan metode drill dalam proses pembelajaran memahami kalimat pasif (passive voice) pada berbagai tenses di kelas XI RPL 1 SMK Negeri Pangandaran tahun pelajaran 2017/2018.

2. Untuk mengetahui efektifitas penggunaan metode drill dalam meningkatkan kemampuan memahami kalimat pasif (passive voice) pada berbagai tenses siswa kelas XI RPL 1 SMK Negeri Pangandaran tahun pelajaran 2017/2018.

\section{METODE PENELITIAN}

Penelitian ini dilaksanakan di SMK Negeri 1 Pangandaran yang beralamat di Jalan Merdeka Nomor 222, Kecamatan Pangandaran, Kabupaten Pangandaran, kode pos 46396. Subyek penelitian ini adalah siswa-siswi kelas XI RPL 1 SMK Negeri 1 Pangandaran tahun pelajaran 2017/2018 yang berjumlah 35 orang.

Prosedur penelitian ini mengikuti model sebagaimana kerangka berpikir yang dikembangkan oleh Supardi (dalam Arikunto, 2008:104), berupa siklus spiral yang meliputi kegiatan perencanaan, pelaksanaan tindakan, observasi dan refleksi yang membentuk siklus demi siklus sampai tuntas penelitian.

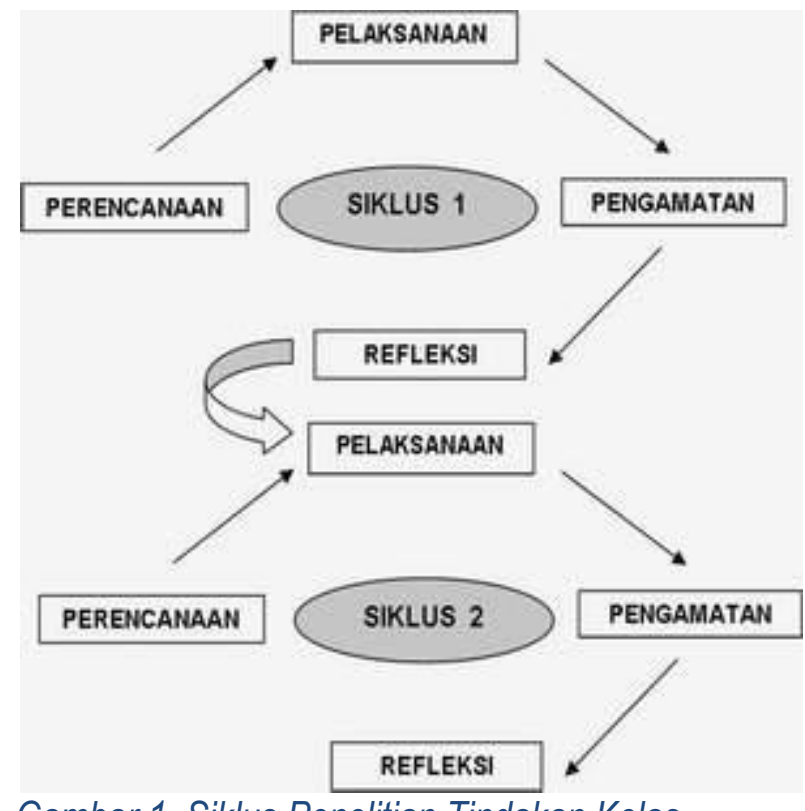

Gambar 1. Siklus Penelitian Tindakan Kelas

Untuk memperoleh data yang akurat, peneliti menggunakan beberapa teknik yang antara lain sebagai berikut:

a. Teknik Observasi

Observasi yaitu pengamatan dan pencatatan secara sistematis terhadap gejala atau fenomena yang diselidiki (Marzuki, 2000:58). Kegiatan observasi ini mengamati kinerja guru dan perilaku siswa kelas XI RPL 1 ketika melaksanakan proses pembelajaran kalimat pasif sebelum dan sesudah diberi tindakan melalui metode drill. 


\section{b. Metode Tes}

Menurut Zainal Arifin (dalam Suriamiharja, 1997:5), tes adalah suatu teknik atau cara dalam rangka melaksanakan kegiatan evaluasi, yang di dalamnya terdapat berbagai item atau serangkaian tugas yang harus dikerjakan atau dijawab oleh anak didik atau siswa, kemudian pekerjaan dan jawaban itu menghasilkan nilai tentang perilaku anak didik atau siswa tersebut.

Tes pada penelitian ini dilaksanakan pada setiap akhir siklus yang berupa tes tulis pilihan ganda. Pemberian tes ini dimaksudkan untuk mengukur pemahaman siswa kelas XI RPL 1 SMK Negeri 1 Pangandaran tahun pelajaran 2017/2018 tentang kalimat pasif sebelum dan sesudah diberi tindakan melalui metode drill.

Data hasil observasi dianalisis secara kualitatif. Teknik analisis data terdiri dari tiga tahap pokok, yaitu reduksi data, paparan data dan penarikan kesimpulan. Reduksi data merupakan proses pemilihan data yang relevan, penting, bermakna, dan dan data yang tidak berguna untuk menjelaskan tentang apa yang menjadi sasaran analisis. Langkah yang dilakukan adalah menyederhanakan dengan membuat jalan fokus, klasifikasi dan abstraksi data kasar menjadi data yang yang bermakna untuk dianalisis. Data yang sudah direduksi selanjutnya disajikan dengan cara mendeskripsikan dalam bentuk paparan data yang memungkinkan untuk ditarik kesimpulan. Kesimpulan merupakan intisari dari analisis yang memberikan pernyataan tentang dampak dari penelitian tindakan kelas.

Sedangkan data kuantitatif dianalisa dengan menggunakan analisis deskriptif dan sajian visual. Sajian tersebut untuk menggambarkan bahwa dengan tindakan yang dilakukan dapat menimbulkan adanya perbaikan, peningkatan, dan atau perubahan ke arah yang lebih baik jika dibandingkan dengan keadaan sebelumnya.

Adapun teknik analisis interaktif, menurut Iskandar (2008:222) adalah teknik analisis yang prosesnya dilakukan dengan tiga langkah, yaitu (1) reduksi data; (2) penyajian data; dan (3) penarikan kesimpulan atau verifikasi.

1. Hasil observasi terhadap kinerja guru diolah dengan menggunakan rumus sebagai berikut.

Skala kualitas $1=$ kurang baik Rata-rata $3.26-4.00=$ Kategori Sangat Baik

Skala kualitas $2=$ cukup baik

Rata-rata $2.51-3.25=$ Kategori Baik

Skala kualitas $3=$ baik

Rata-rata $1.76-2.50=$ Kategori Cukup

Skala kualitas 4 = sangat baik

Rata-rata $1.00-1.75=$ Kategori Kurang

2. Hasil observasi terhadap perilaku siswa diolah dengan menggunakan rumus sebagai berikut.

Skala kuantitas $1=\leq 25 \%$ siswa

Skala kuantitas $2=26 \%-50 \%$ siswa

Skala kuantitas $3=51 \%-75 \%$ siswa

Skala kuantitas $4=76 \%-100 \%$ siswa
Rata-rata $3.26-4.00=$ Kategori Sangat Baik

Rata-rata $2.51-3.25=$ Kategori Baik

Rata-rata $1.76-2.50=$ Kategori Cukup

Rata-rata $1.00-1.75=$ Kategori Kurang

3. Hasil tes diolah untuk mengetahui jumlah nilai, nilai tertinggi, nilai terendah, nilai rata-rata kelas (tingkat penguasaan materi), dan ketuntasan belajar.

Ketuntasan belajar $=$ Jumlah siswa yang mendapat nilai $\geq 75$

Jumlah siswa keseluruhan

\section{HASIL PENELITIAN}

Proses pembelajaran memahami kalimat pasif di kelas XI RPL 1 SMK Negeri 1 Pangandaran tahun pelajaran 2017/2018 melalui metode drill adalah metode yang berpusat pada guru. Artinya, peneliti tidak hanya berfungsi sebagai model bahasa yang diajarkan tetapi juga mengawasi arah dan kecepatan belajar serta memantau dan mengoreksi hasil belajar. Tujuannya adalah memudahkan siswa kelas XI RPL 1 memahami kalimat pasif secara efektif dan efesien (Tarigan, 1989:140). Metode ini merupakan metode yag menekankan pada pengulangan latihan. 
Proses pembelajaran memahami kalimat pasif di kelas XI RPL 1 SMK Negeri 1 Pangandaran tahun pelajaran 2017/2018 melalui metode drill memiliki tujuan agar siswa kelas XI RPL 1 dapat mencapai keterampilan berbahasa Inggris terutama memahami kalimat pasif. Menurut Armai, (2002:175) metode drill dapat membantu siswa memiliki ketrampilan moroeis/gerak, misalnya menghafal katakata. Terkait dengan menghapal kata-kata, metode drill ini diharapkan dapat meningkatkan pemahaman siswa tentang materi kalimat pasif dalam bahasa Inggris.

Keberhasilan metode ini ditunjang oleh langkah-langkah yang tepat yang harus dilakukan oleh guru, diantaranya: mempersiapkan pertanyaan-pertanyaan atau perintah-perintah beserta jawabannya; mengajukan pertanyaan secara lisan, tertulis, atau memberikan perintah untuk melakukan sesuatu; mendengarkan jawaban lisan atau memeriksa jawaban tertulis atau melihat gerakan yang dilakukan; mengajukan kembali berulang-ulang pertanyaan atau perintah yang telah diajukan dan didengar jawabannya.

Semua fase teknik metode drill tersebut diharapkan mampu membantu siswa kelas XI RPL 1 dalam memahami kalimat pasif bahasa Inggris. Selain itu, melalui teknik metode drill diharapkan dapat meningkatkan pengetahuan siswa dari berbagai segi dan siswa tersebut akan memperoleh pemahaman yang lebih baik dan lebih mendalam.

Di dalam penelitian ini, peneliti menerapkan langkah-langkah pembelajaran metode drill sebagaimana yang dinyatakan oleh Majid (2014:214) berikut ini: siswa mendapat pengertian yang mendalam sebelum diadakan latihan tertentu; dalam percobaan kembali harus diteliti kesulitan yang timbul; respons yang benar harus diperkuat; kemudian diadakan variasi, perkembangan arti dan control; masa latihan secara relatif singkat, tetapi harus sering dilakukan.; pada waktu latihan harus dilakukan proses esensial. (perlu sekali; mendasar).

Di dalam latihan yang pertama-tama adalah ketepatan, kecepatan dan pada akhirnya keduaduanya harus dapat tercapai sebagai kesatuan peneliti melaksanakan beberapa langkah yang biasa dilakukan dalam proses pembelajaran.

Proses pembelajaran memahami kalimat pasif di kelas XI RPL 1 SMK Negeri 1 Pangandaran tahun pelajaran 2017/2018 melalui metode drill ini memberikan perhatian utama kepada kegiatan latihan, drill, dialog, teks bacaan, dan kandungan isinya, serta kemampuan siswa kelas XI RPL 1 untuk berinteraksi dan berkomunikasi. Penerapan metode ini hampir sama dengan penerapan pengajaran bahasa pertama pada anak-anak, anak-anak menguasai bahasa ibunya melalui peniruan. Peniruan itu biasanya diikuti oleh pujian atau perbaikan.

Melalui kegiatan itulah anak-anak mengembangkan pengetahuannya mengenai struktur, pola kebiasaan bahasa ibunya. Maka hal yang sama juga diberlakukan dalam pengajaran memahami kalimat pasif bahasa Inggris ini. Melalui cara peniruan dan penguatan, para siswa kelas XI RPL 1 mengidentifikasi hubungan antara stimulus dan response yang merupakan kebiasaan dalam berbahasa.

Hasil penelitian ini membuktikan bahwa metode drill membuat para siswa kelas XI RPL 1 menjadi terampil dalam membuat dan menyusun pola-pola kalimat yang sudah dilatihkan, mempunyai ucapan, ejaan yang baik dan benar, dan terus menerus memberi respon pada rangsangan yang telah diberikan guru. Hal ini dijelaskan Tarigan (1991:139) (a) guru yang terampil sangat dibutuhkan, (b) ulangan sering kali membosankan serta menghambat penghipotesisan kaidah-kaidah bahasa, dan (c) kurang sekali memperhatikan pada tuturan spontan. Oleh karena itu, peneliti memodifikasi metode ini sebagai suatu improvisasi guru dalam pembelajaran. Berikut ini adalah tabel dan histogram yang memuat data-data penelitian terkait kinerja guru dan Hasil analisis terhadap kinerja guru

Tabel 1.

Data-data penelitian terkait kinerja guru Hasil analisis terhadap kinerja guru

\begin{tabular}{llll}
\hline Kriteria & Pra Siklus & Siklus 1 & Siklus 2 \\
\hline Jumlah skor & 10 & 14 & 18 \\
Rata-rata skor & 1.66 & 2.33 & 3.00 \\
Kategori & Kurang & Cukup & Baik \\
\hline
\end{tabular}




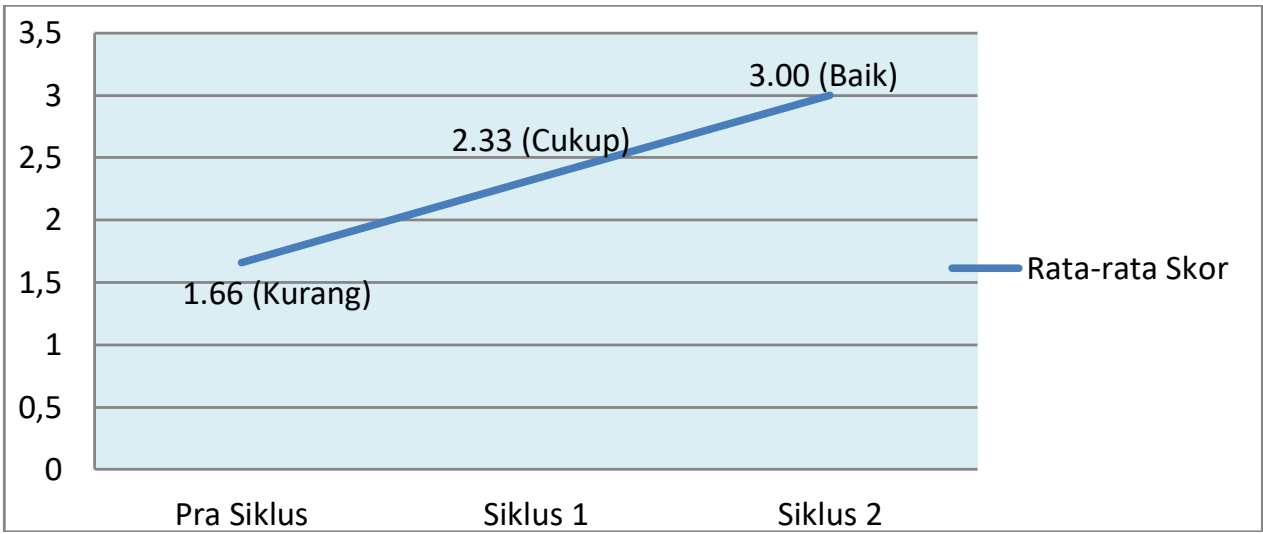

Gambar 2. Histogram hasil analisis terhadap kinerja guru

Dari tabel di atas dapat diketahui bahwa ada peningkatan pada kinerja guru. Pada tindakan pra siklus rata-rata skor kinerja guru adalah 1.66 (kategori kurang). Di akhir siklus 2, rata-rata skor kinerja guru meningkat menjadi 3.00 (kategori baik). Ini berarti bahwa indikator keberhasilan untuk kinerja guru telah tercapai.

Di bawah ini adalah tabel dan histogram yang memuat data penelitian terkait perilaku siswa.

\section{Tabel 2}

Hasil analisis terhadap perilaku siswa

\begin{tabular}{llll}
\hline Kriteria & Pra Siklus & Siklus 1 & Siklus 2 \\
\hline Jumlah skor & 12 & 25 & 30 \\
Rata-rata skor & 1.20 & 2.50 & 3.00 \\
Kategori & Kurang & Cukup & Baik \\
\hline
\end{tabular}

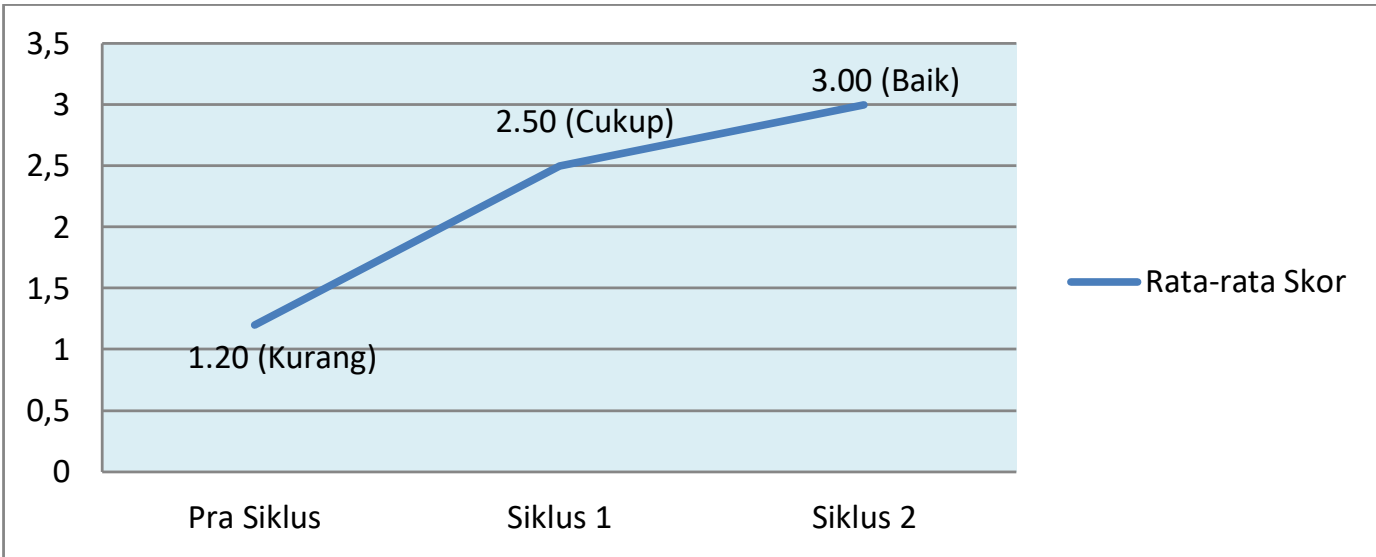

Gambar 3. Histogram hasil analisis terhadap perilaku siswa

Dari tabel 2 dapat diketahui bahwa ada peningkatan pada perilaku siswa. Pada tindakan pra siklus rata-rata skor perilaku siswa adalah 1.20 (kategori kurang). Di akhir siklus 2, rata-rata skor perilaku siswa meningkat menjadi 3.00 (kategori baik). Ini berarti bahwa indikator keberhasilan untuk perilaku siswa telah tercapai.

Di bawah ini adalah tabel dan histogram yang memuat data penelitian terkait kemampuan siswa kelas XI RPL 1 dalam memahami kalimat pasif.

Tabel 3

Hasil analisis terhadap nilai tes

\begin{tabular}{llll}
\hline Kriteria & Pra Siklus & Siklus 1 & Siklus 2 \\
\hline Tingkat Penguasaan Materi & $65.2 \%$ & $79.6 \%$ & $90.9 \%$ \\
Ketuntasan Belajar & $13.0 \%$ & $82.6 \%$ & $100 \%$
\end{tabular}




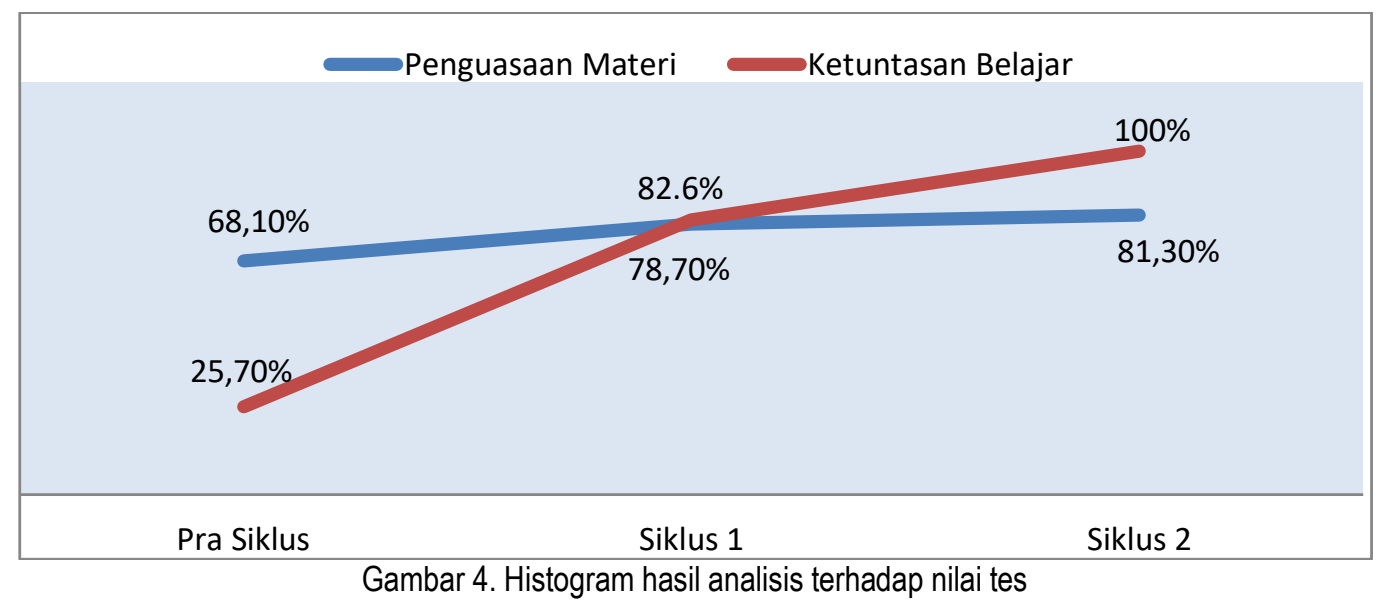

Dari data di atas dapat diketahui bahwa pada siklus 2 ketuntasan belajar mencapai $100 \%$. Ini berarti bahwa indikator keberhasilan penelitian pada aspek kemampuan siswa telah tercapai. Dari tabel dan diagram di atas, peneliti melihat adanya peningkatan dalam tingkat penguasaan materi (nilai rata-rata kelas). Pada tindakan pra siklus penguasaan materi adalah sebesar $68.1 \%$. Di akhir siklus 2, jumlah ini meningkat menjadi $81.3 \%$. Ini berarti bahwa total peningkatan pada persentase penguasaan materi adalah sebesar $13.2 \%$. Sedangkan ketuntasan belajar, pada tindakan pra siklus persentasenya adalah $25.7 \%$. Pada siklus 2, jumlahnya meningkat menjadi $100 \%$. Peneliti menghitung peningkatan persentase ketuntasan belajar adalah sebesar $74.3 \%$.

\section{SIMPULAN DAN SARAN}

Hasil penelitian menyatakan bahwa ada peningkatan dalam tingkat penguasaan materi (nilai rata-rata kelas) sebesar $13,2 \%$. Sedangkan peningkatan dalam persentase ketuntasan belajar sebesar $74,3 \%$. Selain itu, metode drill terbukti dapat meningkatkan perilaku siswa kelas XI RPL 1 ketika proses pembelajaran berlangsung. Berdasarkan hasil penelitian tersebut dapat disimpulkan bahwa metode drill terbukti dapat meningkatkan pemahaman siswa kelas XI RPL 1 SMK Negeri 1 Pangandaran tahun pelajaran 2017/2018 tentang kalimat pasif.

Adapun saran saran-saran yang dapat peneliti berikan adalah sebagai berikut:

1. Siswa disarankan untuk lebih aktif mengikuti pembelajaran dan tetap memperhatikan perkembangan teknologi dan informasi yang ada sehingga ilmu pengetahuan dan wawasan dapat terus bertambah.

2. Bagi guru-guru diharapkan dapat melakukan penelitian-penelitian yang kreatif dan inovatif tentang mengajar dengan menggunakan media dan metode yang berbeda-beda sehingga metode dalam mengajar bisa lebih beragam.

\section{DAFTAR PUSTAKA}

Arikunto, S. (2008). Penelitian Tindakan Kelas. Jakarta: Bumi Aksara.

Armai, A. (2002). Pengantar IImu dan Metodologi Pendidikan Islam. Jakarta: Intermasa.

Hamid, F. A. (1987). Proses Belajar Mengajar Bahasa. Jakarta: PPLPTK Depdikbud.

Iskandar. (2008). Metodologi Penelitian Pendidikan dan Sosial (Kuantitatif dan Kualitatif). Jakarta: GP Press.

Marzuki. (2000). Metodelogi Riset fakultas Ekonomi UII Yogyakarta. 
Mulyadi, T. K. (2019). Meningkatkan Kemampuan Berbicara Pada Teks Transaksional Dan Interpersonal Melalui Metode Role Play (Penelitian Tindakan Kelas di Kelas IX-G SMP Negeri 20 Tasikmalaya. Jurnal Wahana Pendidikan, 6(1), 90-96.

Murni, W. (2008). Penelitian Tindakan Kelas. Malang: UM Press.

Nana S. (1995). Penilaian Hasil Proses Belajar Mengajar. Bandung: PT. Remaja Rosdakarya.

Roestiyah, N. K. (2001). Strategi Belajar Mengajar, Jakarta: Rineka Cipta.

Sudaryono. (2012). Dasar-dasar Evaluasi Pembelajaran. Yogyakarta: Graha IImu.

Sudjana, N. (1995). Dasar-Dasar Proses Belajar Mengajar. Bandung: Sinar Baru Algensindo.

Suriamiharja. (1997). Petunjuk Praktis Menulis. Jakarta: Departemen Pendidikan dan Kebudayaan Direktorat Jenderal Pendidikan Dasar dan Menengah Bagian Proyek Penataran Guru SLTP Setara D-III.

Suwandi, S. (2008). Penelitian Tindakan Kelas (PTK) dan Penulisan Karya Ilmiah. Surakarta: Panitia Sertifikasi Guru Rayon 13.

Suyatno. (2004). Teknik Pembelajaran Bahasa dan Sastra. Surabaya: Penerbit ISC

Syaiful Bahri Djamarah dan Aswan Zain. (1996). Strategi Belajar Mengajar. Jakarta: Rineka Cipta.

Tarigan, H. G. (1989). Prinsip-Prinsip Dasar Sastra. Bandung: Angkasa

Tarigan, H. G. (1991). Metodologi Pengajaran Bahasa 1. Bandung: Angkasa.

Zuchdi D. (2007). Strategi Meningkatkan Kemampuan Membaca. Yogyakarta : UNY Press. 